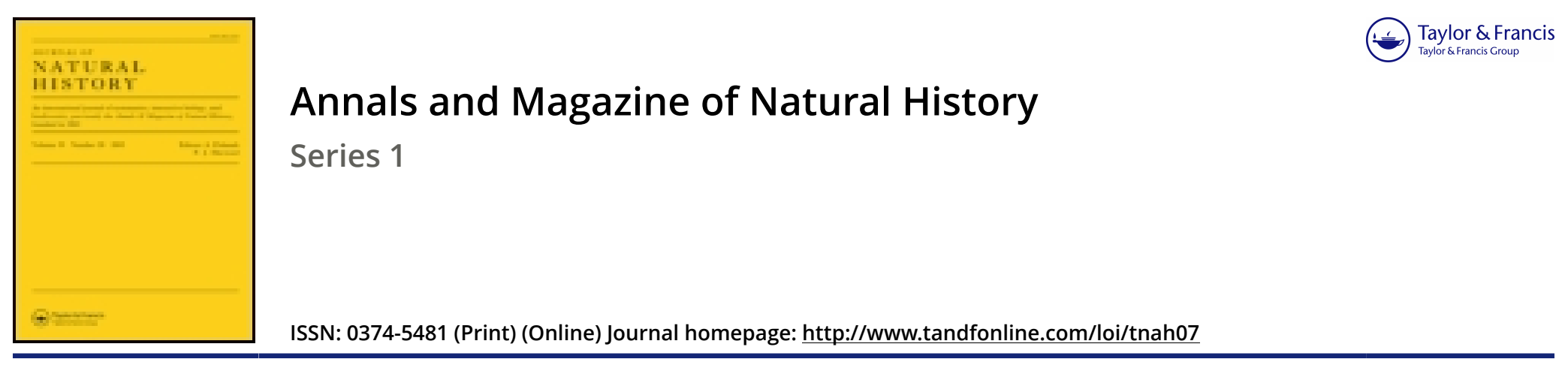

\title{
XV.-Abstract of a paper entitled "Account of a Botanical Tour in North Wales, the South of England and Jersey, during the months of August and September 1843."
}

\section{R. Graham M.D.}

To cite this article: R. Graham M.D. (1844) XV.-Abstract of a paper entitled "Account of a Botanical Tour in North Wales, the South of England and Jersey, during the months of August and September 1843.", Annals and Magazine of Natural History, 13:82, 105-109, DOI: $10.1080 / 03745484409442578$

To link to this article: http://dx.doi.org/10.1080/03745484409442578

\section{曲 Published online: 04 Dec 2009.}

Submit your article to this journal ए

View related articles $\sqsubset$ 
Species dubia.

8. Strongylus. Cavity of thorax of moor-buzzard (Buteo rufus).

9.

'the gapes.' I have found three specimens, each upwards of half an inch in length, in the trachea of a chicken which died of the gapes a fortnight after being hatched, and was informed that it had manifested symptoms of the disease when only fire days old.

In the specimens which I have examined the male portion of the animal (as it has been called) was of a paler colour than the other, and no trace of a convoluted tube was visible through its parietes, though rery evident in the female portion.

[To be continued.]

XV.-Abstract of a paper entitled "Account of a Botanical Tour in North Wales, the South of England and Jersey, during the months of August and September 1843." BY R. GRAHA M, M.D., Professor of Botany in the University of Edinburgh*.

Ix this communication the Professor only noticed such plants observed by lim as are not natives of Scotland, are scarce there, or which otherwise possess interest from marker! peculiarities of geographical distribution in the districts which he visited. The journey extended from Liverpool to Chester, and ihence by St. Asaph to Bangor. From Bangor the Professor and his party walked up Caruedd Llewellyn, sind by the slate quarries of lenrlyn to Ilanberris, botanizing in the woods and valleys in the ne:ghbourhood, ascending Snovdon from the west, and passing on te Capel Curig and the Pevil's Kitchen, from which they went by the mail to Birmin $r_{-}$ham. From Birmingham Dr. Graham proseeded to Dorset shire and Jersey. Whatever was noticed regarding the regetation elserhere was seen only from the coach, or durin- ine almost momentary stoppages at the stages. On returning from Jersey, a few hours were spent in a very hasty examination of the road-side in a corner of the Isle of Wight.

The following are the plants seen in the first balf of the journey, and not truly wild in Scotland :-Lactuca muralis, in a little glen a few miles to the westrard of Chester, aud not again obscrved in the whole journcy; and in the same place, Tamus communis (afterwards found to be very frequent further south); Chlora perfoliata, Helminthia echioides (also profuse near Weymouth); Diplotaxis tenuifolia, abundant on the walls near Ches-

- Read before the Botanical Society of Edinburgh, Dec. 14, 1813. 
ter; Rosa arrensis, Nepeta cataria; Senecio temuifolius, abundant also. further south, but native, as far as is known, in very few localities in Scotland; Sedum dasyphyllum, on walls at Conway; Calamintha officinalis, Foniculum vulgare (also plentiful near Weymouth and in Jcrsey), Orobanche barbata in profusion; and Verbena officinalis.

The Welsh mountains, at least in August, possess very little interest to a Scotch botanist. The alpine species are few compared with the vegetation of the Grampians, and the number of specimens eren of common species is very small. The valleys, howerer, contain in abundance screral plants which are rare in Scotland, or which do not exist there as natives. Among these are Poterium Sanguisorba, Serratula tinctoria, Campanula hederacea. "Thalictrum minus is abundant in several places in Scotland, but we found it at the Devil's Kitchen, at a much higher clevation than I ever recollect seeing it beforc, except in Cunnamara in the west of Ireland. In the same station we also found Arenaria verna, a species which is very abundant near Edinburgh, but which I never before gathered on the west side of the island."

In the Botanic Garden at Birminglam a specimen of Erodium Hymenodes was pointed out, said to have been picked from among many others on the Flat Holmes in the Serern, and which the intelligent curator, Mr. Cameron, said had all the appearance of being a native specimen when brought to him. NIr. Camcron also pointed out a varicty of Sedum Telephium, which he first observed in considerable quantity on the Titterstone Clce Hill, Shropshire, in 1839 , at an eleration of 1400 feet, and had cultivated since 1810 without any alteration in its character cxecpt increase of size. It is distinguished from the ordinary state by its smaller fruit, its procumbent stems, and its long, slender, horizontal, underground stoloniferous shoots.

The plants which appeared characteristic of the neighbourhood of Cheltenham, Bristol and Bath werc-Viburnum Lantana, Clematis Vitalba, Pastinaca sativa, and Convolvulus Sepium; the first three not belonging to the Flora of Scotland, and the last remarkable for its vast profusion in almost crery hedge. 'These plants were obscrved along the whole route to Weymouth, and in addition, between Dorchester and Weywouth were seen Cnicus acaulis and Campanula glomerata ; the latter, however, very small, or at most never acquiring the luxuriant appearance it lias in the neighbourhood of Edinburgh. A few plants of Carduus eriophorus were seen by the road-side a little way to the southward of Bath.

One of the most interesting walks of the whole cxcursion was that of the 16th of August, along the beach parallel to the Chesil 
Bank, as affording a collection of plants most unlike the Scottish Flora. The principal of these were, Braclypodium pimnatum, Iris fotidissima, Tamarix gallica (ccrtainly introduced), Linum angustifolium, Linaria Elatine, Linaria spuria, Lathyrus Nissolia, Lathyrus Aphaca, Trifolium maritimum, Vicia bithynica, Errum tetraspermum, Helminthia echioides, P'etroselinum segetum and Sison Amomum. None of these, it is believed, renlly belong to the Scottish Flora, and not above one or two, if any, have been permanently naturalized in a few stations in Scotland. Besides these, there werc found on the same ground the following plants which are wild, some perhaps only naturalized, in a few localitics to the north of the Tweed:-Hordeum pratense, Sinapis nigra, Trifolium fragiferum, Mcdicago maculata, Vicia lutea, Anthemis nobilis, Serratula tinctoria, Cichorium Intybus, Poterium Sanguisorla, Enanthe pimpinelloides, Linaria vulyaris, rar. Peloria, and a single specinien of a remarkable variety of Plantago Coronopus with many panicled hcads.

The walk on the I7th of August was from Dorchester to Wrareham, and was by no means so productive as that of the day before, yet sercral plants unknown to or scarce in the I'lora of Scotland were observed. Of these, some have been named already, others were the following:-Cornus sanguinea, Scabiosa columbaria, Drosera longifolia, Silene anglica, Galeopsis Ladanum, Antirrhinum Orontium, Ulex nanus (a variety perfectly procumbent, very different from the Scotch or Irish plant), Picris hieracioides, Cuscuta Epithymum. These last two plants are said by Sir W'm. Hooker to be frequent in Scotland, but Dr. Graham has never seen either, nor any species of Cuscuta there, not evidently introduced.

The walk on the 18th of August was from Winfith to Osminton Mill, partly by lanes, partly orer chalk downs, and by the cliffs on the shore. The only plants gathered and not before mentioned, which are not wild in Scotland, though certainly so in the stations where they were then scen, were Ligustrum vulgare, Asperula cynanchica, Inula Conyza and Euphorbia amygdaloides. Others found only in limited stations in Scotland were, Campanula Trachelium, Silaus pratensis and Euphorbia portlandica.

The next walk was on the 24th of August, about half way up the east coast of the Isle of Jersey, where the following plants were gathered:-Bromus diandrus, Cyperus lonyus, Chenopodium murale, Scilla autumnalis, Rumex pulcher, Marrubium vulgare, Matthiola sinuata, Senecio vulgaris, var. radiatus, Euphorbia Paralias, Atriplex laciniata, Erodium moschatum. It was remarked, that of the three species of Paparer-P. Argemone, P. dubium and $P$. Rhoeas - so abundant in the neighbourhood of Edinburgh, only the second was seen in Walcs, only the third in the south of England, and that $P$. dubium again appeared in Jerscy. On the 
26th, accompanied by Dr. Macreight, the walk was along St. Aubin's Bay by La Haule, across the Quenvais to St. Ouen's Bay and the village of St. Oucn. In this route the most interesting plants gathered, and not already named, were, a densely tufted glaucous species of Festuca, with short, erect, very rigid and sharp subulate leaves, considercd a form of Festuca ovina, but very unlike any form of that species which has been observed anywhere else; Schanus nigricans, Polycarpon tetraphyllum, Scirpus pungens; Scirpus maritimus, a varicty with unusually clongated peduncles and ovato-lanceolate attenuated spikes; Armeria plantaginea, varying considcrably in the breadth of its leaves, but always distinguishable from $A$. muritima by the want of hairiness upon the scape ; Juncus acutus, Polygonum maritimum, Dianthus prolifer, Oxalis corniculata, Ranunculus hirsutus, Mentha rotundifolia and Orobanche Eryngii? profuse on drift-sand in St. Ouen's Bay. "In adopting this name I by no means wish to give an opinion as to its propriety. It is, I confess, only an attcmpt to escape from the necessity of intermeddling with a subject in almost hopeless confusion. The species of Orobanche are, to say the least, separated by ideal boundaries, and the principle in which $I$ seem to acquiesce by the name I have here given, namely to characterize species by the plants on which they are parasitical, has always appeared to me erroneous. Vaucher found an Orobanche parasitical on Eryngium campestre in the southern provinces of France, and he called it O. Eryngii, and the designation is adopted in the 'Botanicon Gallicum.' Our plant is certainly parasitical on E. maritimum, and upon this very slender ground, for I have not scen a French specimen, I have given it the same name. It is only half parasitical, as I doubt not are all the species; half parasitical in a different sense to that in which the same thing may be said of the species of Cuscuta. These are at onc period of their existence wholly terrestrial, and afterwards wholly parasitical ; but the Orobanche is permanently attached to the extremity of a root of Eryngium, which is there thickened and terminated abruptly, but it sends its orm roots into the sand all around. The roots were so deep in the loose sand, that we failed in many attempts to raise an entire plant of Eryngium with the parasite attached to it ; but Dr. Macreight showed me, that by the peculiar and pungent taste, it was quite certain that the fragment of the root which we often got up with the Orobanche was that of Eryngium maritimum." Other plants of the same day's walk, either local in Scotland or not at all native there, were the following: Sibthorpia europaa, Bartsia viscosa, Diplotaxis muralis, Coronopus didyma, Erigeron acris, Diotis maritima, Centaurea Calcitrapa, Spiranthes autumnalis, Amuranthus Blitum, Asplenium lanceolatum, Asplenium marinum.

On the 2nd of September, again accompanied by Dr. Macreight, we walked by St. Brelade round the south-west corner of the island 
to La Moye and the southern extremity of the Quenvais. The following plants werc picked in this route: Isolepis Sarii, Rubia peregrina, Centunculus minimus, Echium violaceum, Datura Stramonium; Scilla autumnalis in great profusion and beauty, both of its usual colour and also with white flowers; Rumex maritimus, Silene nutans, Cistus gutlatus, Antirrhinum Orontium, Trifolium subterrancum, Gnaphalium luteo-allum, Hieracium umbellatum. On other days in which a few minutes only could be given to botany, Grammitis Ceterach was picked from the churchyard wall of St. Saviour's, the only situation in which it was seen in the island; and in the same place what has been called Mercurialis ambigua, but there and evergwhere else in Jersey every variety of form from this to the most usual condition of Mercurialis annua may be found; Scrophularia Scorodonia was met with in crery lane; Carex extensa was gathered near Rozel Harbour. In a pasture field near La IIaule was gathered Verbascum nigrum, in such variety as to show that the character of this specics must hare a uide range as to the shape of the leaves, the amount of tomentum, and the length of the petioles.

The 1lth of September was the last day spent in Jersey, and a rapid glance was taken of the regetation of the Town Hill and Gallows Ilill in the immediate vicinity of St. Helier's. On the former was gathered Crithmun maritimum nearly two feet high, Statice spathulata of very large size and in very fine condition, Atriplex portulacoides, Senebiera didyma and Polycarpon tetraphyllum; the last two grow also in the less frequented strcets of St. IIclier's. On Gallows Hill were found Herniaria glabra, $\beta$ subciliata, Centaurea solstitialis, and Amaranthus Blitum in better condition than elsewhere.

On leaving Jersey Dr. Graham and his friends went to Southampton, where they were met by $D_{1}$. Bell Salter, and, accompanied by him, went to Cowes and drove to Rydc, leaving the carriage only while ascending the hills. Even this glimpse of the vegetation of the Isle of W'ight however was most interesting, and furnished a long list of South-of-England plants. Gastridium lendigerum had not been seen before, and is very common in the Isle of Wight. Silaus pratensis is a local plant in Scotland. From Dr. Bromfield specimens of Cyperus longus, Chenopodium glaucum, and Calamintha officinalis of unusual form and large size were received. Doubts were entertained of the specific identity of the last with the British plant already recognised as Calamintha officinalis; but it will probably turn out to be the extremity of a chain which may be traced into the usual form through a plant which in $\mathbf{2 8 3 0}$ the late Mr. Christy gathered at Fishponds, Gloucester, and one which Mr. Roberts gathered at Craig Millar Castle near Edinburgh in 1836. 